\title{
Liraglutide exhibits anti-inflammatory activity through the activation of the PKA/ CREB pathway
}

\author{
Li Wang $^{1 *}$ D, Linjie Feng ${ }^{2}$ and Jingyu Zhang ${ }^{1}$
}

\begin{abstract}
Qihong Que and colleagues found that liraglutide exhibited anti-inflammatory activity through the activation of the PKA/CREB pathway in an OA rat model. We believe there was a flaw in this research. In their first experiment, the sacrifice time of the 10 rats in the control group has not been stated. And when the rats in the OA-1, OA-5, OA-10, OA-20 and OA-28 groups were sacrificed, they were in different weeks of age. If the rats in the control group were compared to the rats in the OA-1, OA-5, OA-10, OA-20 and OA-28 groups respectively, the results may be biased due to differences in the week age of the rats. We believe that addressing this issue could further increase the value of their study.
\end{abstract}

Keywords: GLP-1R, Liraglutide, PKA/CREB pathway, Inflammation, Osteoarthritis

\section{Main text}

Qihong Que. and colleagues [1] found that liraglutide exhibited anti-inflammatory activity through the activation of the PKA/CREB pathway in an OA rat model. We believe there was a flaw in this research. In their first experiment, the sacrifice time of the 10 rats in the control group has not been stated. And when the rats in the OA-1, OA-5, OA-10, OA-20 and OA-28 groups were sacrificed, they were in different weeks of age. If the rats in the control group were compared to the rats in the OA-1, OA-5, OA-10, OA-20 and OA-28 groups respectively, the results may be biased due to differences in the week age of the rats. We believe that addressing this issue could further increase the value of their study.

We declare no competing interests.

\section{Conclusions}

Qihong Que. and colleagues found that liraglutide exhibited anti-inflammatory activity through the activation of the PKA/CREB pathway in an OA rat model. We believe there was a flaw in this research.

\footnotetext{
* Correspondence: tseywl@126.com

1Department of Hand Surgery, The Second Hospital of Tangshan, No. 21 Jianshe Road, Tangshan, Hebei, 063000 Tangshan, Hebei, People's Republic of China

Full list of author information is available at the end of the article
}

\begin{abstract}
Abbreviations
CREB: cyclic adenosine monophosphate (CAMP) response element-binding; OA: osteoarthritis; PKA: protein kinase A
\end{abstract}

\section{Acknowledgements}

Not applicable.

\section{Authors' contributions}

LW was a major contributor in writing the manuscript. All authors read and approved the final manuscript.

\section{Funding}

No funding was obtained for this study.

\section{Availability of data and materials}

Not applicable.

\section{Ethics approval and consent to participate} Not applicable.

\section{Consent for publication}

Not applicable.

\section{Competing interests}

The authors declare that they have no competing interests.

\section{Author details}

${ }^{1}$ Department of Hand Surgery, The Second Hospital of Tangshan, No. 21 Jianshe Road, Tangshan, Hebei, 063000 Tangshan, Hebei, People's Republic of China. ${ }^{2}$ Department of Orthopedics, North China University of Science and Technology Affiliated Hospital, Tangshan, Hebei, People's Republic of China. 
Received: 11 July 2019 Accepted: 27 September 2019

Published online: 11 October 2019

\section{Reference}

1. Que Q, Guo X, Zhan L, et al. The GLP-1 agonist, liraglutide, ameliorates inflammation through the activation of the PKA/CREB pathway in a rat model of knee osteoarthritis. J Inflamm (Lond). 2019;16:13.

\section{Publisher's Note}

Springer Nature remains neutral with regard to jurisdictional claims in published maps and institutional affiliations.

Ready to submit your research? Choose BMC and benefit from:

- fast, convenient online submission

- thorough peer review by experienced researchers in your field

- rapid publication on acceptance

- support for research data, including large and complex data types

- gold Open Access which fosters wider collaboration and increased citations

- maximum visibility for your research: over $100 \mathrm{M}$ website views per year

At $B M C$, research is always in progress. 